\title{
Role of granites in genesis of Archean VHMS systems, WA examples
}

\author{
S.G. TESSALINA ${ }^{1 *}$, B. WARE ${ }^{1}$, V.BARROTE ${ }^{1}$, \\ N.J. MCNAUGHTON ${ }^{1}$ \\ ${ }^{1}$ JDLC, Curtin University, Kent St Bentley 6102 WA, \\ (*correspondance: Svetlana.Tessalina@curtin.edu.au)
} Australia

The Archean VHMS-style mineralisation shows a strong spatial association to coeval HFSE granites [1]. To continue to investigate the role of these granites in ore genesis, we examine $\mathrm{Pb}$ isotope signatures for Archean examples from the Pilbara and Yilgarn cratons. In the case of $c a .3 .5 \mathrm{Ga}$ old North Pole deposit, syngenetic pyrite was deposited before the emplacement of an adamellite massif (Fig. 1). However, $\mathrm{Pb}$ from epigenetic galena corresponds to initial ratios determined from a $\mathrm{Pb}-\mathrm{Pb}$ isochron for adamellite. In a case of the $c a$. $3.2 \mathrm{Ga}$ old Sulphur Spring deposit, ore galena $\mathrm{Pb}$ is derived solely from the local granite and ore-hosting volcanic pile, as displayed by concordance with a $\mathrm{Pb}-\mathrm{Pb}$ isochron. In the Teutonic Bore camp, the local granite massif is slightly younger than the lower ore-bearing stratigraphy, but remains as the potential heater necessary to fuel the hydrothermal system. For these Archean hydrothermal systems, the granites could be a fuel/source of metals of primary syngenetic and/or later epigenetic mineralisation. The $\mathrm{Pb}$ isotope data from these three Archean hydrothermal systems continue to display the dynamic role of granites in their formation.

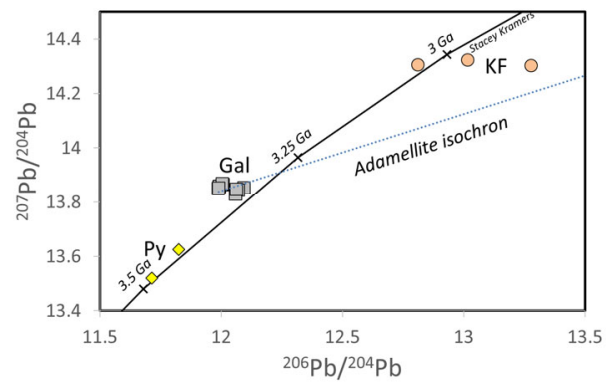

Figure 1. ${ }^{206} \mathrm{~Pb}^{204} \mathrm{~Pb}$ vs ${ }^{207} \mathrm{~Pb}^{204} \mathrm{~Pb}$ plot of ore pyrite (Py) and galena ( $\mathrm{Gal}[2])$, as well as adamellite and $\mathrm{K}$-feldspat (KF) form North Pole area, Pilbara Craton.

[1] Hollis et al (2015) Precambr Res 260, 113-135. [2] Richards et al (1981) Miner Depos 16, 7-30. 